\title{
Prayer as God-knowledge (via Self)
}

\begin{abstract}
What is the purpose of prayer? According to Kierkegaard, "prayer does not change God, but it changes the one who prays." Whilst much contemporary philosophy of religion focuses on the so-called puzzle of petitionary prayer, less is written about how prayer can change the person who prays. In this paper, I discuss Kierkegaard's account of prayer in The Sickness unto Death and "An Occasional Discourse on the Occasion of Confession.” Prayer, as it is presented here, allows a person to gain a certain kind of self-knowledge and thereby draw near to God. After outlining Kierkegaard's account, I draw some comparisons with Harry Frankfurt's account of the will to demonstrate how prayer might allow for both self-knowledge as well as God-knowledge.
\end{abstract}

\section{Introduction}

Recent work on the philosophy of prayer has focused almost entirely on the question of how a person's prayer could change the mind of God. This is the so called "puzzle of petitionary prayer." ${ }^{1}$ However, not all philosophers or theologians agree that prayer should primarily seek to change the mind of God. The Danish thinker Søren Kierkegaard, for instance, writes that "prayer does not change God, but it changes the one who prays." ${ }^{2}$ This is a line of thought which those who engage with the puzzle of petitionary prayer are familiar with. Daniel and Frances Howard-Synder, for instance, state that,

[w]e agree that petitioning God can make a difference in us. However...most practicing theists assume there is more to it than that and so it would be more charitable to solve

I would like to thank David Efird and an anonymous referee for their helpful feedback on earlier drafts of this paper. Thanks also go to the members of the St. Benedict Society for philosophy of religion and philosophical theology at the University of York for their helpful comments, as well as to the participants of the Annual Christian Philosophy Conference for their feedback.

1 Daniel and Frances Howard-Snyder, "The Puzzle of Petitionary Prayer," European Journal for Philosophy of Religion, vol. 2, 2010, pp. 43-68.

2 SKS 8, 137 / UD, 22.

Joshua Cockayne, Department of Philosophy, University of York, York YO10 5DD, United Kingdom, :josh.cockayne@york.ac.uk

https://doi.org/10.1515/kierke-2017-0005 
the puzzle without denying their assumption. Moreover, even if petitioning God can make a difference in us, we cannot petition him while thinking that our words won't make any difference to whether he does what we ask. ${ }^{3}$

The Howard-Snyders acknowledge that the kind of thinking behind Kierkegaard's view on prayer is valuable, but irrelevant to the puzzle of petitionary prayer. Yet, in focusing only on the petitionary aspect of prayer, the philosophy of Christian prayer risks becoming skewed in focus. Even if we disagree with Kierkegaard's conclusion (that prayer only changes us, and not God), the question that seems pertinent to ask is: How does prayer change the person who prays?

In this paper, I argue that the purpose of prayer is to gain knowledge of oneself. However, this is not the kind of knowledge one can gain merely by introspecting-the account of prayer I will focus on here aims to draw a person closer to God through their knowledge of self. To do this, I focus on the short, but intriguing, account of prayer that we find in Kierkegaard's The Sickness unto Death. Kierkegaard's pseudonymous author, Anti-Climacus, writes, "to pray is...to breathe, and possibility is for the self what oxygen is for breathing." "What does Anti-Climacus mean by this remark? In presenting this passage in the wider context of The Sickness unto Death, I argue that prayer as it is presented here is best understood as an activity which enables a person to gain a kind of self-knowledge. More specifically, in seeing what AntiClimacus writes about the human self as a synthesis of necessity and possibility, we can see prayer as an activity of becoming more aware of our existence as creatures who express both necessity (we are physical, mortal creatures) and possibility (it is possible for us to somehow transcend this earthly life and the constraints of everyday physical existence). After discussing Kierkegaard's account of prayer and self-knowledge in The Sickness unto Death, I draw a comparison between Kierkegaard's Harry Frankfurt's accounts of the will. ${ }^{5}$ Drawing on Frankfurt's notion of wholeheartedness, I describe the Kierkegaardian notion of despair as a kind of internal conflict of the will which is irresolvable without intervention from God; despair cannot be overcome, Anti-Climacus tells us, until the soul "rests transparently in God." To explain what generates this internal conflict, I argue that all human beings have a first-order desire for union with

3 Howard-Synder and Howard-Snyder, "The Puzzle of Petitionary Prayer,” p. 46.

4 SKS 11, 156 / SUD, 40.

5 Harry Frankfurt, The Importance of What We Care About, Cambridge: Cambridge University Press 1988.

6 SKS 11, 146 / SUD, 30. 
God which is often supressed, ignored, or misunderstood. It is only when this desire for God is unified with a higher-order desire for union with God that a person can be free of despair and come close to God. Thus, it follows, in order for a person to come close to God in faith, she must become conscious of her inherent desire for God. That is, prayer makes possible a kind of Godknowledge via self-knowledge. ${ }^{7}$

\title{
II Kierkegaard on Prayer
}

Those familiar with Kierkegaard's writings will know that they are littered with short, and often profound, examples of prayers. ${ }^{8}$ Kierkegaard also offers some thoughts on the purpose of prayer, at places in his writings. In his "Occasional Discourse on the Occasion of Confession," for instance, Kierkegaard discusses an example of a confessional prayer. Kierkegaard writes that

\begin{abstract}
[a] hasty explanation can suppose that to pray is a futile act because a person's prayer does not, of course, change the changeless; but in the long run would this be desirable, could not the changing person easily come to repent that he managed to get God changed! Thus, the true explanation is also the one and only to be desired: the prayer does not change God, but it changes the one who prays. ${ }^{9}$
\end{abstract}

According to Kierkegaard, to pray is not to seek to change God's mind, or at least not in the context of a confession, but rather, to pray is to seek to change oneself. Whilst it appears that Kierkegaard seeks to disregard petitionary prayer altogeth-

7 Some points of clarification: First, this paper is not an attempt to offer a solution to the problem of petitionary prayer. The claim that prayer primarily changes us and not God is not a satisfying response to the problem of petitionary prayer, yet this does not mean that prayer as a means of self-knowledge is without philosophical interest (although this may explain the lack of exploration of this kind of prayer by analytic philosophers). Secondly, there is much to be said on Kierkegaard's discussion of self-knowledge (for discussions of Kierkegaard and self-knowledge, see John Lippitt's "Self-Knowledge in Kierkegaard," in Self-Knowledge, ed. by Ursula Renz, Oxford: Oxford University Press 2016; or Daniel Watts's "Kierkegaard and the Search for Self-Knowledge,” European Journal of Philosophy, vol. 4, 2013, pp. 525-549). There is not scope for a broad overview of what Kierkegaard writes on self-knowledge here. My focus will primarily be to give an account of prayer which draws on aspects of Kierkegaard's thinking, rather than to offer a systematic overview of Kierkegaard's thoughts on the topics of either self-knowledge or prayer.

8 These are compiled in The Prayers of Kierkegaard, ed. by Perry D. Le Fevre, Chicago: The University of Chicago Press 1956.

9 SKS 8, 137 / UD, 22. 
er here, we need not reach such a drastic conclusion to follow Kierkegaard's thoughts on prayer. As the Howard-Snyders acknowledge, it is entirely possible for prayer to change both the individual and God. The question that I am interested in exploring here concerns what difference prayer makes to the pray-er.

What is the nature of this change? In the context of the discourse, we find this discussion of confessional prayer alongside Kierkegaard's discussion of the human will. Kierkegaard describes faith as a kind of single-mindedness in which an individual has the purity of heart to will only the good. And it is this purity of heart and single-mindedness of the will which allows a person to draw near to God. Kierkegaard writes that "only the pure in heart are able to see God and consequently keep near to him."10 When Kierkegaard speaks of "nearness" to God or "distance" from God, we should read this in terms of willed distance from God. Although God never distances himself from us, the result of despair and sin is a willed distance from God-human beings choose to be far from God by lacking a purity of heart to will the good.

Conversely, it is a person's lack of ability to will only the good, or their being in a state of sin, which means that they will not to come near to God. Sin, as it is discussed here, is a kind of despair in which a person has two wills; ${ }^{11}$ although a person wills the good and wills to be close to God, she is double-minded or conflicted in her will. For instance, she might pursue the good for some selfish purpose such as for some reward, ${ }^{12}$ or fear of punishment. ${ }^{13}$ Or, Kierkegaard tells us, a person can be double-minded by only partially willing the good through busyness or distraction. ${ }^{14}$ Hence, the prayer of confession seeks to change a person by a change of the will. Prayer then seeks to bring about a change from double-mindedness to single-mindedness in a person.

This discussion of prayer as a response to double-mindedness is picked up two years later by Kierkegaard in the pseudonymously signed The Sickness unto Death. Here, the author, Anti-Climacus, develops a similar account of faith, sin, and despair, albeit in more philosophical terms. According to Anti-Climacus, the universal human condition is that of despair. Despair, as it is defined in Sickness, is a wilful misrelation to oneself. Either through ignorance, weakness, or defiance, a person can be in a state of despair by failing to will to be a self in the appropriate way. Anti-Climacus defines the self as a "synthesis of the

10 SKS 8, 138 / UD, 24.

11 SKS 8, 144 / UD, 30.

12 SKS 8, 152 / UD, 41.

13 SKS 8, 156 / UD, 44.

14 SKS 8, 72 / UD, 64. 
infinite and the finite, of the temporal and the eternal, of freedom and necessity, in short, a synthesis." 15 As Murray Rae describes it, this is an attempt to maintain the tension which is found in the biblical view of the self; human beings are but dust (Gen 3:19), yet, they "have been made a little lower than God" (Ps 8:5). ${ }^{16}$

Despair is a failure of the will in relation to the self. As it is described later in Sickness, it is the basis of human sin. The kind of despair Anti-Climacus has in mind is summarised well by the words of the Anglican confession: "Father...we have sinned against you... through ignorance, through weakness, through our own deliberate fault."17 A person can express despair because of their lack of self-awareness, through a kind of weakness of will or through a kind of defiance. Hence, despair is closely related to a person's self-knowledge. AntiClimacus writes that "[t]he more consciousness, the more self; the more consciousness, the more will; the more will, the more self. A person who has no will is not a self; but the more will he has, the more self-consciousness he has also."18 Thus, despair is a kind of internal conflict of a person's will in which she cannot or refuses to will to be a self.

The discussion of the will in Sickness is related to that in the "Occasional Discourse." Here Kierkegaard describes the sin of double-mindedness as a kind of despair ("what else is it to despair but to have two wills!"19) Despair as a wilful misrelation to oneself (e.g., to despair through a lack of possibility) can be understood in terms of double-mindedness too. As Anti-Climacus repeatedly emphasises, what the person in despair lacks is the condition of faith in which a person is free from despair and can relate properly to God. AntiClimacus explicitly calls the condition "the good" 20 in places. If despair is a fragmentation of the will in which there is conflict, faith is the antidote to this conflict; faith is characterized by resting in God and willing only the good.

One of the key ways a person can exist in despair is by failing to exist as a synthesis in the manner which Anti-Climacus is vital for existing as a self. Since a person is a synthesis of necessity and possibility, a person can fall into despair because they lack either necessity or possibility in how they live. For instance, the despair of possibility is characterised by someone who lives a fantastical life full of imagination, hopes and dreams but who never sees these dreams ac-

15 SKS 11, 129 / SUD, 13.

16 Murray Rae, Kierkegaard and Theology, Edinburgh: T\&T Clark 2010, p. 92.

17 Church of England, "A Form of Preparation," in Common Worship, from: https://www. churchofengland.org/prayer-worship/worship/texts.aspx [last accessed July 2016].

18 SKS 11, 145 / SUD, 29.

19 SKS 8, 144 / UD, 30.

20 SKS 11, 213 / SUD, 101. 
tualized. "What is missing" from such a life, Anti-Climacus tells us "is essentially the power to obey, to submit to one's limitations." ${ }^{21}$ Although it is vital that a person expresses possibility in how they live, without expressing necessity, a person is not fully a self, and thus exists in despair, according to AntiClimacus. He writes that "[p]ossibility is like a child's invitation to a party; the child is willing at once, but the question now is whether the parents will give permission-and as it is with the parents, so it is with necessity."22 Conversely, just as a person falls into despair through possibility alone, a person who exists only through necessity also exists in despair. Such a condition, AntiClimacus compares to a kind of "fatalism." 23 To despair by lacking possibility is to submit oneself to the facts of one's situation-although one cannot exist by expressing only the possible, to exist without any possibility is resign oneself to the inevitably and uncontrollability of the future. Crucially, what the fatalist lacks is the possibility of faith. From the perspective of the fatalist, salvation is impossible and human beings are condemned to despair. AntiClimacus states that "[t]he believer has the ever infallible antidote for despair -possibility-because for God everything is possible at every moment. This is the good health of faith." ${ }^{24}$ Faith is presented as the antidote to the condition of despair-if there is God for whom all things are possible, fatalism is false.

It is against this backdrop that we find Anti-Climacus account of prayer. $\mathrm{He}$ tells us that

[t]he fatalist is in despair, has lost God and thus his self, for he who does not have a God does not have a self, either. But the fatalist has no God, or, what amounts to the same thing, his God is necessity; since everything is possible for God, then God is this-that everything is possible. Therefore the fatalist's worship of God is at most an interjection, and essentially it is a muteness, a mute capitulation: he is unable to pray. To pray is also to breathe, and possibility is for the self what oxygen is for breathing. Nevertheless, possibility alone or necessity alone can no more be the condition for breathing of prayer than oxygen alone or nitrogen alone can be that for breathing. For to pray there must be a God, a self-and possibility-or a self and possibility in a pregnant sense, because the being of God means that everything is possible, or that everything is possible means the being of God...That God's will is the possible makes me able to pray, if there is nothing but necessity, man is essentially as inarticulate as the animals. ${ }^{25}$

21 SKS 11, 152 / SUD, 36.

22 SKS 11, 152 / SUD, 37.

23 SKS 11, 155 / SUD, 40.

24 SKS 11, 155 / SUD, 39- 40.

25 SKS 11, 155-156 / SUD, 40-41. 
The fatalist is in despair since he lacks possibility. The analogy that is used here is of breathing-possibility provides oxygen for an individual, yet a person cannot exist by only breathing oxygen. The fatalist lacks the ability to pray because to pray is to relate to a God for whom all things are possible, not least is the possibility of one's own salvation. Prayer, as it is presented here requires a basic level of self-awareness-remember, despair is a condition of a person's will and the fatalist, through ignorance, defiance, or weakness is unable to pray since he is unable to express possibility.

Not only does prayer require a level of self-knowledge but also it brings with it a kind of self-knowledge. The human self, in Anti-Climacus's presentation, is not static but something which requires a perpetual act of the will. Thus, to exist as a synthesis of necessity and possibility requires a kind of breathing-a person must be constantly breathing in possibility in Anti-Climacus's metaphor. ${ }^{26}$ The implication of this analogy is that prayer allows a person to become more self-aware. Prayer is a perpetual reminder that for God all things are possible. Furthermore, since the human self is a synthesis of necessity and possibility, by relating to God as the source of possibility, one comes to be aware that she does not exist as a purely necessary being.

As with the discussion of prayer in the occasional discourse, Anti-Climacus describes prayer as something which brings about change in the individual; this is a change in a person's self-awareness. Prayer brings home this fact that I am a synthesis of the necessary and the possible-I exist as a mortal, physical thing who is condemned to despair, yet I breathe in the possibility of faith, that for God all things are possible. Or, to put it more simply, prayer allows a person to gain knowledge of themselves. We also find this claim about self-knowledge and prayer in “Occasional Discourse.” Kierkegaard writes:

The person confessing is not like someone confiding in a friend, whom he initiates, in advance or afterward, into something he did not know before; the Omniscient One does not find out anything about the person confessing, but instead the person confessing finds out something about himself. Therefore, do not raise the objection against the confession that there is no benefit in confiding to an omniscient one what he already knows; first answer the question whether it does not benefit a person to find out something about himself that he did not know! ${ }^{27}$

We can see more clearly that the change brought about through prayer (from double-mindedness to single-mindedness) is a change of knowledge. A person

26 This is one way of interpreting St. Paul's command to "pray continually" (cf. 1 Thess 5:17). 27 SKS 8, 137 / UD, 22. 
comes to know something through the act of praying. According to Kierkegaard, the practice of prayer draws a person before God to reflect on their sin; if the fatalist were more self-conscious, he would realise that he is not merely a necessary, physical being, but rather, he relates to a God for whom all things are possible. Not only this, but also the fatalist cannot draw near to God because of his sin. The revelation of God through prayer brings home the fact that a person is in despair and in despair a person cannot relate to God in faith. For Kierkegaard, self-knowledge is an essential part of our coming to know God. In a journal entry, he puts it as follows:

Paganism required: Know yourself. Christianity declares: No, that is provisional, know yourself and then look at yourself in the Mirror of the Word in order to know yourself properly. No true self-knowledge without God-knowledge or [without standing] before God. To stand before the Mirror means to stand before God. ${ }^{28}$

Prayer as self-knowledge is only half of the picture, for Kierkegaard. True selfknowledge must not only relate to the self, but must also relate to God. As Anti-Climacus writes, "[t]he human self is such a derived, established relation that relates itself to itself and in relating itself to itself relates itself to another."29 To will only the good, a person must come to will to be in union with God. And thus, a person can only single-mindedly will the good when they are able to "rest transparently in God." 30

\section{Wholeheartedness}

Kierkegaard's model of prayer as a means of coming to know God (via self) is promising as a model of prayer. In the remainder of this paper, I will develop this account of prayer by drawing on Harry Frankfurt's analysis of the will to try and further shed light on how prayer can bring about self-knowledge and

28 SKS 24, 425, NB24:159 / JP 4, 3902.

29 SKS 11, 129 / SUD, 13-14.

30 SKS 11, 146 / SUD, 30. The idea that knowledge of self is important for knowledge of God has some precedence in the spiritual/theological literature: "[F]irst flows self-knowledge and from this source arises knowledge of God" (John of the Cross, Dark Night of the Soul, trans. by Mirabai Starrm, New York: Riverhead Books, 2002, pp. 78-79.) See also John Calvin: "Nearly all the wisdom which we possess, that is to say, true and sound wisdom, consists of two parts: the knowledge of God and of ourselves. But, while joined by many bonds, which one precedes and brings forth the other is not easy to discern." (John Calvin, Institutes of the Christian Religion, abridged version, London/Louisville: Westminster John Knox Press, p. 1.) 
why this might in turn allow for an increased knowledge of God. Similarly to Anti-Climacus, Frankfurt states that the human will has an essential role to play in our understanding of personhood. ${ }^{31}$ He writes,

[i]t is my view the one essential difference between persons and other creatures is to be found in the structure of a person's will. Human beings are not alone in having desires and motivations, or in making choices. They share these things with the members of certain other species, some of whom appear to engage in deliberation and to make decisions based upon prior thought. It seems to be peculiarly characteristic of humans, however, that they are able to form what I shall call "second order desires." ${ }^{32}$

For Frankfurt, to will is to be able to form second-order desires. ${ }^{33}$ The difference between first-order and second-order desires, as Frankfurt defines it, is that firstorder desires are desires "to do or not to do one thing or another," ${ }^{34}$ whereas second-order desires are desires which are directed towards first-order desires. A second-order desire is a desire to desire something. An example will help to make this clearer. I may have the first-order desire to gorge myself on chocolate every night and I might also have the first order desire not to get too fat. I might also have certain second-order desires: the desire not to desire chocolate so often, or a desire to have a greater desire to not get too fat, for example. Now, the will, in Frankfurt's terminology is simply "an effective desire-one that moves (or will or would move) a person all the way to action." ${ }^{35}$ Willing differs from intending, for instance, in that "even though someone may have a settled intention to do $\mathrm{X}$, he may nonetheless do something else instead of doing $\mathrm{X}$ because, despite his intention, his desire to do $\mathrm{X}$ proves to be weaker or less effective than some conflicting desire." ${ }^{36}$ Thus, I may fail to will to desire less chocolate if my second-order desire to desire less chocolate fails to be effective. That is, if I want my desire for selfcontrol to trump my desire for delicious chocolate, and I eat the delicious

31 I appreciate that "selfhood" in Anti-Climacus's account and "personhood" in Frankfurt's discussion might not be equivalent, but, as we will see, there is sufficient similarity in what these two accounts are interested in describing that the application of Frankfurt's account of the will is still a helpful comparison to make.

32 Frankfurt, The Importance of What We Care About, p. 12.

33 Note the similarity here with what Anti-Climacus has to say: "[t]he possibility of this sickness [despair] is man's superiority over the animal” (SKS 11, 131 / SUD, 15). Or, in other words, the capacity to will, or more precisely, a failure to will, distinguishes human beings from other animals.

34 Frankfurt, The Importance of What We Care About, p. 12.

35 Ibid., p. 14.

36 Ibid., p. 14. 
chocolate, I have failed to will effectively. This kind of second-order desire, in which a person wants a desire to be his will, is what Frankfurt calls a "second order volition." 37

Just as we found in Kierkegaard's writings, Frankfurt argues that the human will can be distorted or in conflict in various ways. On Frankfurt's account, a person has a hierarchy of desires; some of our desires play a more crucial role than others, and some of our less important desires are subordinate to more important desires. My desire to be a morally good person, for instance, trumps my desires for having as much fun as possible. Thus, when my desire for having fun conflicts with my desire for moral goodness, I desire to have the second-order volition to will the right action, and not the most fun action. Because of the possibility of having hierarchy and structure in our desires, it is possible to lack what Frankfurt calls "wholeheartedness" (Kierkegaard's term “double-mindedness" looks just as appropriate here) when our internal desires conflict in some way. ${ }^{38}$ In such a case, Frankfurt remarks,

[i]t is not a matter of volitional strength but of whether the highest-order preferences concerning some volitional issue are wholehearted. It has to do with the possibility that there is no unequivocal answer to the question of what the person really wants, even though his desires do form a complex and extensive hierarchical structure. There might be no unequivocal answer, because the person is ambivalent with respect to the object he comes closest to really wanting: In other words, because with respect to that object, he is drawn not only toward it but away from it too. Or there might be no unequivocal answer because the person's preferences concerning what he wants are not fully integrated, so that there is some inconsistency or conflict (perhaps not yet manifest) among them. ${ }^{39}$

Wholeheartedness is a structural property of one's will in which a person has a freedom of will because their desires are integrated in the appropriate way. That

37 Ibid., p. 16.

38 Rudd makes this comparison between single-mindedness and wholeheartedness. He notes that contrary to Frankfurt's subjective understanding of wholeheartedness, for Kierkegaard, "only the Good can be willed wholeheartedly" (Antony Rudd, "Kierkegaard's Platonism and the Reasons of Love," in Love, Reason and Will: Kierkegaard after Frankfurt, ed. by Antony Rudd and John Davenport, New York and London: Bloomsbury 2015, p 254).

39 Frankfurt, The Importance of What We Care About, p. 165. This kind of conflict of the will can also occur because of a kind of ignorance towards one's desires, according to Frankfurt: "It is possible for a human being to be at times, and perhaps even always, indifferent towards his own motives-to take no evaluative attitude toward the desires that incline him to act. If there is a conflict between those desires, he does not care which of them proves to be more effective. In other words, the individual does not participate in the conflict. Therefore, the outcome of the conflict can be neither a victory for him nor a defeat." (Frankfurt, The Importance of What We Care About, p. 164.) 
is, there is nothing internally about a person's desires or volitions which is preventing them from willing in a certain way.

This analysis can easily be extended to think about the conflict of will we find in Kierkegaard's analysis of double-mindedness and despair. Understood in these terms, Kierkegaard's notion of despair is a condition of lacking wholeheartedness, of not being able to will effectively. In particular, despair is the condition of failing to will only the good because of the conflict of one's will due to a lack of wholeheartedness or internal fragmentation. However, whereas Frankfurt's notion of wholeheartedness is a structural property of the will, for Kierkegaard, there is something more objective about single-mindedness. ${ }^{40}$ Kierkegaard's account of single-mindedness, in contrast to Frankfurt's, depends not only on the structure of a person's will, but also on whether or not that person wills the good. And unlike Frankfurt, Kierkegaard has a clear idea of how a person's will needs to be integrated in order to be wholehearted. As both Kierkegaard and Anti-Climacus describe it, human beings are unable to be content until they "rest transparently in God"41 or "will only the good." 42 As Anthony Rudd describes, for Kierkegaard,

[o]n the...Kierkegaardian view...I need to appeal to standards outside of me-to the True and the Good-and if I find I am averse to them, then this is not something to be accepted, but to be struggled against. If there is a genuinely authoritative standard, then choices made with reference to that standard are not arbitrary. This can I think, help us to see the force of Kierkegaard's claim that it is only through being orientated to God that the self is able to hold together the elements of transcendence and immanence in creative tension, and that the loss of that orientation necessarily results in the internal conflict, or self-mutilation that Kierkegaard calls 'despair' or 'sin'. At any rate, we can see why it seem plausible to claim that the self needs an orientation to the Good to prevent it from despairing in this sense. ${ }^{43}$

40 Frankfurt's account of wholeheartedness is susceptible to the following kind of counter examples: "Eve is a strong, independent young woman. She longs for an education and career of her own. Unfortunately, she has been born into a strict, religious community. In that community, women are expected to be meek and compliant, to accept male authority, to remain uneducated, and maintain a subservient societal role. Eve rejects those values and insists that she be respected as fully equal to anyone else. But after years of failure, condemnation, and psychological and physical abuse, she breaks down. She starts to accept the subservient role. She becomes a willing convert." (Bruce N. Waller, Against Moral Responsibility, Cambridge, Mass.: MIT Press 2011, p. 61.)

41 SKS 11, 146 / SUD, 30.

42 SKS 8, 138 / UD, 24.

43 Rudd, "Kierkegaard's Platonism and the Reasons of Love,” pp. 258-59. 
In order to make sense of this account in Frankfurtian terms, then, we must claim that human beings have an inherent first-order desire for the good which will always conflict with one's other desires until one becomes wholehearted. If one can only be content by resting transparently in God, then one way of making sense of this is that resting transparently in God satisfies a certain desire, even if one was unaware of this desire. It is only when one is able to have an effective second-order volition to will the good that a person's desires become structured in such a way that there is no conflict.

\section{Prayer as God-knowledge (via Self)}

The implication of the Kierkegaardian/Frankfurtian account of the will I have been considering is that it is only by submitting to the will of God that a person be truly free and wholehearted. The ultimate good for human beings, as we have seen, Anti-Climacus repeatedly emphasise, is to "rest transparently in God." ${ }^{44}$ If it is true that human beings possess an inherent desire for God which must be integrated around a higher-order desire for goodness, then the more self-aware one becomes, the more one realises that the only way of unifying one's desires and will is by coming closer to God.

This account of wholeheartedness can help us to see how Christian faith and sin are related to the will in more precise terms. The result of human sin is that human beings lack the resources to come into union with God, since their desires are not aimed at the good. They fail to will to be a self since they lack the higherorder desire which can fully integrate their will. For Anti-Climacus, faith is a gift from God which provides the antidote to despair. We can understand this in Frankfurtian terms: faith is the reception of the higher-order desire to will the good, around which all of a person's desires can be integrated. The life of faith, then, is a life of reintegration of a person's desires and will so that, eventually, they may be wholehearted in their desire for the good..$^{45}$ The practice of prayer can be seen as a crucial part of this process of reintegration. For the person who has received the gift of faith and the higher-order desire for the good, the purpose of prayer is to become more self-aware, to discover where one's desires are not unified around the good, and where one is not singleminded.

44 SKS 11, 146 / SUD, 30.

45 Eleonore Stump also draws on Frankfurt's analysis of higher-order desires to explain her Thomistic view of the ordo salutis; cf. Eleonore Stump, Wandering Darkness, Oxford: Oxford University Press 2010. 
How is it possible for prayer to bring a person out of despair and eventually closer to God? John Lippitt, in his discussion of Kierkegaard's account of selfknowledge, describes a person's self-knowledge in first person, third person and second personal terms. He writes that self-knowledge seeks "to understand $\sin$ as an objective property in which all humanity is implicated, but to relate to this on a first-person, subjective level as something that applies to me. Standing 'before God' (second-person) is what brings this home." ${ }^{46}$ As Lippitt reads Kierkegaard's discussion of self-knowledge, true self-knowledge requires us to come close to God and it is in this encounter with God that a person comes to realise the extent of their sin and their distance from God. To continue the application of Frankfurt's terminology-by experiencing God in prayer, a person comes to realise that they have a deep-seated desire for union with God and that this conflicts with their other desires. Furthermore, this conflict (or despair) is the very thing which prevents this person from enjoying a closeness in relationship to God. Only through a purity of the will can a person come to know God, but in experiencing God, a person comes to realise that their will is too fragmented to wholeheartedly will to be in union. It is this realisation that my desire and my will prevent me from the one thing that can bring wholeheartedness, that I can begin the process of reintegration. The key difference between the kind of self-knowledge made possible in prayer, and all other kinds of introspection or self-knowledge, then, is that prayer begins before God and the content of self-knowledge relates to a person's will and desires.

As Eleonore Stump argues, in order for persons to be close to one another, there has to be a mutual self-revelation in which both person's share their thoughts and feeling freely. ${ }^{47}$ However, if a person is fragmented because of a lack of wholeheartedness, then this precludes the possibility of personal closeness:

A person alienated from himself cannot have someone else close to him. Jerome cannot reveal his mind to Paula if Jerome has hidden a good part of his mind from himself. And, if Jerome desires not to have the desires he has with regard to Paula, then to that extent he does not desire closeness with Paula either. For that matter, if Jerome is divided within himself as regards any of his desires, Paula will be distant from some part of Jerome, no matter which of his conflicting desires she allies herself with. So, for Paula to be close to Jerome, it is necessary that Jerome be integrated in himself. ${ }^{48}$

46 John Lippitt, “Self-knowledge in Kierkegaard,” p. 16.

47 Stump, Wandering in Darkness, p. 120.

48 Stump, Wandering in Darkness, p. 125. 
Stump's account of personal closeness can be extended to think about closeness with God. Anti-Climacus writes that Christianity teaches that a person is "invited to live on the most intimate terms with God"; ${ }^{49}$ we can see despair as a kind of fragmentation that prevents this kind of intimacy from occurring. In short, those living in a state of despair, or double-mindedness, are not able to be close to God because there are parts of themselves which are hidden even to their own consciousness. Thus, when Anti-Climacus describes prayer as a breathing of necessity and possibility, we can see this as a kind of re-orientation of the self in which a person comes to recognise their own fragmentation (either they lean too heavily towards necessity or too heavily towards possibility).

The crucial feature of this account of prayer, is that this realisation occurs when one is before God. For the fatalist, coming before God brings with it the realisation that everything is possible for God, and thus, it is her own despair which prevents her from drawing near to God as a synthesis of necessity and possibility. Self-awareness is essential for the possibility of being near to God. As we have seen, the practice of prayer makes possible a kind of selfknowledge through the experience of being before God. In turn, this selfknowledge allows a person to realign their will in the appropriate way, and thus, to draw close to God.

49 SKS 11, 199 / SUD, 85. 